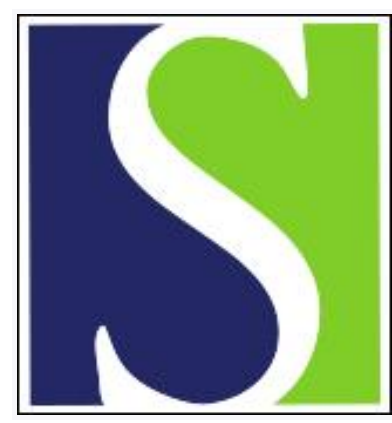

Scand J Work Environ Health 1995;21(6):470-477

https://doi.org/10.5271/sjweh.63

Issue date: Dec 1995

Radiographic small lung opacities and pleural abnormalities as a consequence of asbestos exposure in an adult population by Zitting AJ, Karjalainen A, Impivaara O, Tossavainen A, Kuusela T, Mäki J, Huuskonen MS

The following article refers to this text: 2001;27(2):154-155

Key terms: ILO classification; lung fibrosis; occupation; parietal pleura; pleura; pleural adherence; pleural calcification; pleural plaque; pleural thickening; pneumoconioses; thoracic radiography; visceral pleura

This article in PubMed: www.ncbi.nlm.nih.gov/pubmed/8824753 


\title{
Radiographic small lung opacities and pleural abnormalities as a consequence of asbestos exposure in an adult population
}

\author{
by Anders J Zitting, MD, ${ }^{1}$ Antti Karjalainen, MD, Olli Impivaara, MD, ${ }^{2}$ Antti Tossavainen, DTech, ${ }^{1}$ \\ Timo Kuusela, MD, ${ }^{3}$ Juhani Mäki, MSc, ${ }^{2}$ Matti S Huuskonen, MD'
}

\begin{abstract}
Zitting AJ, Karjalainen A, Impivaara 0, Tossavainen A, Kuusela T, Mäki J, Huuskonen MS. Radiographic small lung opacities and pleural abnormalities as a consequence of asbestos exposure in an adult population. Scand $J$ Work Environ Health 1995;21:470-7.
\end{abstract}

\begin{abstract}
Objectives The purpose of this study was to estimate the role of past asbestos exposure as a cause of radiographic small lung opacities and pleural abnormalities in the Finnish adult population.

Methods The study was conducted in 1978-1981 and was based on a population sample $(\mathrm{N}=8000)$ representative of the Finnish population aged 30 years or over. Full-size chest radiographs and a complete job title history were available for 3811 women and 3274 men. The radiographs were classified according to the 1980 classification of radiographs of pneumoconioses published by the International Labour Office and the work histories according to the probability of occupational asbestos exposure. Age- and smoking-adjusted relative risks of radiographic parenchymal and pleural abnormalities were calculated with the analysis of covariance according to the probability of asbestos exposure.

Results About $13 \%$ of the men and $0.8 \%$ of the women were classified as probably exposed to asbestos. There was more than $90 \%$ agreement in the repeated work history evaluations. The risk of small lung opacities was significantly increased among the probably exposed men [risk ratio (RR) 1.7 for ILO profusion category $1 / 1$ or more and RR 1.6 for profusion category $1 / 0$ ]. The risk of pleural plaques was increased both among the men (RR 3.0) and the women (RR 4.8) with probable exposure. The risk of thickened horizontal interlobar fissure was also increased among the probably exposed men (RR 1.7). Among the men, the etiologic fraction attributable to occupational asbestos exposure was about $30 \%$ for small lung opacities, about $40 \%$ for pleural plaques, and about $20 \%$ for thickened horizontal fissure. Among the women the etiologic fractions for asbestos were similar for pleural abnormalities, but much lower for parenchymal ones.

Conclusions Occupational asbestos exposure has been common among Finnish men, and it plays a significant role in the etiology of both pleural and parenchymal abnormalities also at the level of the general population.
\end{abstract}

Key terms ILO 1980 Classification of Pneumoconioses; lung fibrosis; occupations; pleura, parietal; pleura, visceral; pleural adherences; pleural calcification; pleural plaques; pleural thickening; thoracic radiography.

Small lung opacities are radiographic abnormalities encountered in interstitial pulmonary fibrosis following the inhalation of asbestos fibers (asbestosis), but may also be due to various other causes (1). Pleural plaques are common sequelae of past exposure to asbestos (2). Thickening of the visceral pleura may be a consequence of asbestos exposure, but may also be due to various other causes (3). The International Classification of Radiographs of Pneumoconioses published by the International Labour Office (ILO) offers a standard for classifying small lung opacities and other pulmonary and pleural abnormalities (4).

1 Finnish Institute of Occupational Health, Helsinki, Finland.

2 The Research and Development Centre of the Social Insurance Institution, Turku, Finland.

3 Retired

Reprint requests to: Dr Anders Zitting, Finnish Institute of Occupational Health, Department of Occupational Medicine, Topeliuksenkatu 41 a A, FIN-00250 Helsinki, Finland.
Previous studies have shown that radiographic findings indicating pulmonary fibrosis and pleural abnormalities are frequent among Finnish workers exposed to asbestos in the production of asbestos, the manufacture of asbestos products, housebuilding, and shipyard work $(5,6,7)$. It has been estimated that altogether 200000 Finnish workers have been exposed to asbestos at work during the past few decades (8) and that about $20 \%$ of urban men in Finland show pulmonary fiber concentrations indicative of occupational exposure to asbestos (9). It is therefore to be expected that asbestos-related pulmonary and pleural abnormalities are 
frequent also at the level of the general population in Finland.

The purpose of this study was to estimate the role of asbestos exposure as a cause of radiographic small lung opacities and pleural abnormalities in a population sample representative of the Finnish adult population.

\section{Subjects and methods}

\section{Subjects}

This study is part of the Mini-Finland Health Survey based on a stratified two-stage population sample ( $\mathrm{N}=$ 8000 ) representative of the Finnish population aged 30 years or over (ie, 1.17 million men and 1.38 million women) (10). The study was conducted in 1978-1981. Our report is based on the 7095 persons $(89 \%$ of the sample) on whom full-size chest radiographs acceptable for ILO classification were available. Table 1 presents the population characteristics of the study subjects.

\section{Questionnaires and interviews}

The health survey included a standardized self-administered questionnaire mailed along with the invitation to attend the examination. The questionnaire was checked by a specially trained interviewer in a personal interview during the health examination. The questionnaire included 107 items on personal data, health status, medication, disability, occupational history, leisure activities, and alcohol consumption.

The duration and job title of each occupation held for at least one year were recorded. In addition the job title, duration, employer, and description of the current (or latest) occupation and the occupation with the longest duration were recorded. Smoking, as reported in an inter- view, was classified into the following three categories: current smoker, former smoker, and never a smoker. Full data were available for 7085 persons (3274 men and 3811 women).

\section{Classification of work histories}

The work histories of the subjects were classified into three exposure categories according to the probability of occupational exposure to asbestos. As there were no specific questions related to asbestos exposure in the questionnaire, the classification was based on the general knowledge on asbestos exposure in various jobs and industries in Finland. The classification was as follows [codes of the 1963 Nordic Classification of Occupations (11) in parentheses]: (i) probable exposure (439 men, 29 women): persons employed for at least 10 years as a housebuilding or shipyard worker (codes 755, 761, 774, 781-799); (ii) possible exposure (1734 men, 1389 women): persons employed for at least one year in any industrial occupation (codes 001-014, 501-631, $731-754,756-759,762-773,775-779,811-819$, 832-902, 931-932); and (iii) unlikely exposure (1101 men, 2393 women): persons with life-long employment in farming or forestry, office work, telecommunication work, textile work, health care occupations or housekeeping (codes 015-441, 641 - 726, 801-804, 821$829,903-921,941-991)$

The work histories were classified independently by two experts of occupational medicine and industrial hygiene (AK and AT, 5015 and 2080 cases, respectively). To evaluate the consistency, we classified a subsample of 526 randomly selected work histories in a pilot classification. They were then mixed with the remaining 6569 work histories and reclassified in the final classification four months later. In the reclassification 299 work histories were classified by the same rater as four months earlier, and 227 were seen by the other rater.

Table 1. Asbestos exposure by age and smoking history for 3274 Finnish men and 3811 Finnish women.

\begin{tabular}{|c|c|c|c|c|c|c|c|c|c|c|c|c|c|c|c|c|}
\hline & \multicolumn{8}{|c|}{ Men } & \multicolumn{8}{|c|}{ Women } \\
\hline & \multicolumn{2}{|c|}{$\begin{array}{l}\text { Probably } \\
\text { exposed }\end{array}$} & \multicolumn{2}{|c|}{$\begin{array}{l}\text { Possibly } \\
\text { exposed }\end{array}$} & \multicolumn{2}{|c|}{$\begin{array}{l}\text { Unlikely } \\
\text { exposed }\end{array}$} & \multicolumn{2}{|c|}{ All } & \multicolumn{2}{|c|}{$\begin{array}{l}\text { Probably } \\
\text { exposed }\end{array}$} & \multicolumn{2}{|c|}{$\begin{array}{l}\text { Possibly } \\
\text { exposed }\end{array}$} & \multicolumn{2}{|c|}{$\begin{array}{l}\text { Unlikely } \\
\text { exposed }\end{array}$} & \multicolumn{2}{|c|}{ All } \\
\hline & $\mathrm{N}$ & $\%$ & N & $\%$ & $N$ & $\%$ & N & $\%$ & $N$ & $\%$ & $N$ & $\%$ & $N$ & $\%$ & $N$ & $\%$ \\
\hline \multicolumn{17}{|l|}{ Age (years) } \\
\hline $\begin{array}{l}30-44 \\
45-54 \\
55-64 \\
65-74 \\
\text { over } 75\end{array}$ & $\begin{array}{r}111 \\
136 \\
103 \\
69 \\
20\end{array}$ & $\begin{array}{r}25.2 \\
31.0 \\
23.5 \\
15.7 \\
4.6\end{array}$ & $\begin{array}{r}828 \\
410 \\
272 \\
174 \\
50\end{array}$ & $\begin{array}{r}47.8 \\
23.6 \\
15.7 \\
10.0 \\
2.9\end{array}$ & $\begin{array}{r}386 \\
227 \\
216 \\
186 \\
86\end{array}$ & $\begin{array}{r}35.1 \\
20.6 \\
19.6 \\
16.9 \\
7.8\end{array}$ & $\begin{array}{r}1325 \\
773 \\
591 \\
429 \\
156\end{array}$ & $\begin{array}{r}40.5 \\
23.6 \\
18.1 \\
13.1 \\
4.8\end{array}$ & $\begin{array}{l}4 \\
6 \\
8 \\
9 \\
2\end{array}$ & $\begin{array}{r}13.8 \\
20.7 \\
27.6 \\
31.0 \\
6.9\end{array}$ & $\begin{array}{r}478 \\
338 \\
281 \\
223 \\
69\end{array}$ & $\begin{array}{r}34.4 \\
24.3 \\
20.2 \\
16.1 \\
5.0\end{array}$ & $\begin{array}{l}851 \\
473 \\
449 \\
401 \\
219\end{array}$ & $\begin{array}{r}35.6 \\
19.8 \\
18.8 \\
16.8 \\
9.2\end{array}$ & $\begin{array}{r}1333 \\
817 \\
738 \\
633 \\
290\end{array}$ & $\begin{array}{r}35.0 \\
21.4 \\
19.4 \\
16.6 \\
7.6\end{array}$ \\
\hline All & 439 & 100 & 1734 & 100 & 1101 & 100 & 3274 & 100 & 29 & 100 & 1389 & 100 & 2393 & 100 & 3811 & 100 \\
\hline \multicolumn{17}{|l|}{ Smoking history } \\
\hline $\begin{array}{l}\text { Gurrent smoker } \\
\text { Former smoker } \\
\text { Never smoker }\end{array}$ & $\begin{array}{r}175 \\
171 \\
93\end{array}$ & $\begin{array}{l}39.9 \\
39.0 \\
21.2\end{array}$ & $\begin{array}{l}689 \\
572 \\
473\end{array}$ & $\begin{array}{l}39.7 \\
33.0 \\
27.3\end{array}$ & $\begin{array}{l}328 \\
376 \\
397\end{array}$ & $\begin{array}{l}29.8 \\
34.2 \\
36.1\end{array}$ & $\begin{array}{r}1192 \\
1119 \\
963\end{array}$ & $\begin{array}{l}36.4 \\
34.2 \\
29.4\end{array}$ & $\begin{array}{r}9 \\
5 \\
15\end{array}$ & $\begin{array}{l}31.0 \\
17.2 \\
51.7\end{array}$ & $\begin{array}{r}222 \\
138 \\
1029\end{array}$ & $\begin{array}{l}16.0 \\
13.4 \\
74.1\end{array}$ & $\begin{array}{r}258 \\
218 \\
1917\end{array}$ & $\begin{array}{r}10.8 \\
9.1 \\
80.1\end{array}$ & $\begin{array}{r}489 \\
361 \\
2961\end{array}$ & $\begin{array}{r}12.8 \\
9.5 \\
77.7\end{array}$ \\
\hline All & 439 & 100 & 1734 & 100 & 1101 & 100 & 3274 & 100 & 29 & 100 & 1389 & 100 & 2393 & 100 & 3811 & 100 \\
\hline
\end{tabular}


An effort was also made to compare the exposure classification based on the life-time job history and the classification based on the job title of the current (or latest) occupation only. In this classification the same 280 job title codes were assessed into the categories of probable, possible, and unlikely exposure, but without any knowledge of a person's previous occupations and without any requirement for the duration of employment in addition to the one-year duration requirement used in recording the interview data.

\section{Radiology}

The radiography was performed in a mobile unit. A constant kilovoltage of 120 with automatic exposure control was used. The film-focus distance was $135 \mathrm{~cm}$. A semisensitive film-screen combination giving good resolution was used (Kodak RP film with Kodak X-Omatic regular screens). Full-size chest radiographs (posteroanterior and lateral) acceptable for classification were available for 7095 persons.

Two radiologists recorded the findings according to the ILO 1980 Classification of Radiographs of Pneumoconioses with some additions. The classification of small lung opacities was done independently. In cases of discrepant classification, a joint decision was made. For practical reasons the joint decision was used in calculating the results because the slight dominance that was observed for one of the readers was not found to affect the results substantially. For the pleural abnormalities only a joint decision was made to simplify the classification process.

For the purpose of estimating observer variation, a subsample enriched with findings (597 of the 7095) was reclassified. These radiographs were mixed with the others during the entire classification process. To enable an estimation of interobserver variation regarding pleural abnormalities, all the findings were classified independently in a subsample enriched with pleural abnormalities $(\mathrm{N}=131)$.

In addition to the findings recorded according to the ILO classification, the following abnormalities were recorded: (i) costophrenic angle obliteration less than the lower limit of the ILO classification, but considered definite by both readers and (ii) obliteration of the posterior costophrenic angles. Local pleural thickening of the lateral chest wall with a width of at least $5 \mathrm{~mm}$ seen only in profile was treated as circumscribed thickening if no adherences were present because such thickening has been shown mostly to represent plaques of the parietal pleura (2). Thickening of the horizontal fissure apparent in the posteroanterior radiograph was recorded separately in addition to the ILO symbol pi (pleural thickening in the interlobar fissure or mediastinum). Whether the horizontal fissure was visible in the posteroanterior radiograph was also recorded.
As a means of avoiding false positive findings, irregularities in the diaphragmatic outline were registered as plaques with caution; calcification was considered to be a definite sign of plaques.

In the results, the pleural findings are grouped as follows: (i) circumscribed pleural thickening recorded strictly according to the ILO Classification, bilateral and unilateral; (ii) pleural calcification (bilateral or unilateral); (iii) all the findings indicating plaques of the parietal pleura, unilateral and bilateral: (a) circumscribed or "local" thickening, (b) pleural calcification seen in the posteroanterior radiograph without obliteration of the lateral or posterior costophrenic angle; (iv) costophrenic angle obliteration recorded strictly according to the ILO definition (bilateral or unilateral); (v) findings in the posteroanterior radiograph indicating abnormalities of the visceral pleura, other than fissure thickening; (vi) thickening of the horizontal interlobar fissure (seen in the posteroanterior radiograph); and (vii) all pleural findings, parietal or visceral.

\section{Consistency of the radiographic classification}

As earlier reported (12), the observer agreement concerning pleural abnormalities was rather good. Concerning the profusion of small lung opacities a considerable observer variation occurred, yet mostly comprising only one minor profusion category.

\section{Statistical methods}

The statistical analyses were performed with an analysis of covariance. Exposure class (three classes), age (five classes), and smoking history (current smoker, former smoker, never smoker) were included in the statistical model. The adjusted estimates of relative risk and their $95 \%$ confidence intervals (95\% CI) are given in terms of the prevalence risk ratio (RR).

The etiologic fractions were calculated by multiplying the ratio number of exposed cases: number of all cases by the term (RR-1)/RR. The excess of cases in the categories of probable and possible exposure were included in the etiologic fractions of occupational asbestos exposure.

The kappa statistic was used to estimate the consistency of the exposure classification and the radiographic classification.

\section{Results}

\section{Exposure to asbestos}

About $13 \%$ of the men and $0.8 \%$ of the women were classified as probably having been exposed to asbestos 
according to their past job titles. Among the 439 probably exposed men and 29 women there were 133 carpenters, 37 painters, 36 electricians, 30 plumbers, 24 engineers, 19 concrete workers, 17 masons, 6 pipe insulators, 125 other housebuilding workers, 9 shipyard workers, 12 cleaners, and 20 other maintenance workers. Several possibly exposed persons had worked in various occupations of the transport, metal, ceramic, and paper industries.

\section{Radiological findings}

\section{Small lung opacities}

As previously reported (12), nearly all the small opacities found were classified as irregular (consistent with interstitial lung fibrosis). Small rounded opacities were recorded as the main category in the radiographs of only six persons.

Small lung opacities, ILO profusion categories $1 / 0$ and $\geq 1 / 1$, were more prevalent among the probably exposed men ( 15.3 and $6.2 \%$, respectively) than among the unlikely exposed men (9.5 and $3.8 \%$, respectively) (table 2). After statistical adjustment for age and smoking history, the relative risks of the ILO profusion categories $1 / 0$ and $\geq 1 / 1$ were significantly increased (RR 1.61 and 1.71 , respectively) for the probably exposed men, and that of profusion category $1 / 0$ also for the possibly exposed men (RR 1.80). The risk estimates in table 2 give an etiologic fraction of $31 \%$ for profusion $1 / 0$ and $19 \%$ for profusion $\geq 1 / 1$ when the calculated excess in the categories probably exposed and possibly exposed is related to the total number of cases ( $N=378$ for profusion $1 / 0, \mathrm{~N}=128$ for profusion $\geq 1 / 1$ ).

Among the women, the association of asbestos exposure with the radiographic abnormalities was less evident (table 2), and for the 312 cases of profusion $1 / 0$ and 96 cases of profusion $\geq 1 / 1$ the etiologic fraction was $2 \%$.

\section{Pleural abnormalities}

The prevalences of pleural plaques and calcification were significantly increased among both the probably and possibly exposed men (table 3 ). Bilateral plaques recorded according to the extended definition were present in $13.0 \%$ of the 439 probably exposed, in $6.5 \%$ of the 1734 possibly exposed, and in $4.6 \%$ of the unlikely exposed men (in $6.8 \%$ of all the men). About two-thirds of the findings among the probably exposed men were attributable to occupational exposure to asbestos (RR 3.01) in addition to about one-half of the cases in the category of possibly exposed men (RR 1.97). The etiologic fraction of various findings indicating abnormalities of the parietal pleura, described in table 3, ranged from 37 to $43 \%$. Thickening of the horizontal fissure was significantly more common among the probably exposed men (RR 1.71, 95\% CI 1.072.72) than among the men in the other exposure groups. At least $21 \%$ of all the fissure thickenings were attributable to occupational exposure to asbestos according to the estimated excess in the categories of probably and possibly exposed men. About $32 \%$ of all the pleural findings $(\mathrm{N}=913)$ were attributable to occupational asbestos exposure.

Among the women, abnormalities of the parietal pleura were also highly related to asbestos exposure (table 3). Bilateral plaques were present in about $10 \%$ of the women with probable exposure, $2.7 \%$ of those with possible exposure, and $1.5 \%$ of those with unlikely exposure (in $2.0 \%$ of all the women). The etiologic fractions calculated from the data of table 3 varied from 22 to $33 \%$. About $16 \%$ of all the pleural findings (parietal or visceral) among the women were attributable to occupational exposure to asbestos.

\section{Consistency of the exposure classification}

In a subsample of 526 work histories classified twice at a four-month interval, the two raters agreed in $90 \%$ of the independent evaluations (kappa 0.83), whereas the intra-

Table 2. Prevalence (\%) of and relative risk for small lung opacities by asbestos exposure among 3274 Finnish men and 3811 Finnish women. (ILO = International Labour Office, RR = relative risk adjusted for age and smoking history, $95 \% \mathrm{Cl}=95 \%$ confidence interval)

\begin{tabular}{|c|c|c|c|c|c|c|c|c|c|c|c|c|}
\hline \multirow{2}{*}{$\begin{array}{l}\text { ILO profusion of } \\
\text { small lung opacities }\end{array}$} & \multicolumn{4}{|c|}{ Probably exposed } & \multicolumn{4}{|c|}{ Possibly exposed } & \multicolumn{4}{|c|}{ Unlikely exposed } \\
\hline & $N$ & $\%$ & $\mathrm{RR}$ & $95 \% \mathrm{Cl}$ & N & $\%$ & $\mathrm{RR}$ & $95 \% \mathrm{Cl}$ & $N$ & $\%$ & $R R$ & $95 \% \mathrm{Cl}$ \\
\hline \multicolumn{13}{|l|}{ Men } \\
\hline $\begin{array}{l}\text { Profusion 0/0 } \\
\text { Profusion } 0 / 1 \\
\text { Profusion } 1 / 0 \\
\text { Profusion } \geq 1 / 1\end{array}$ & $\begin{array}{r}160 \\
185 \\
67 \\
27\end{array}$ & $\begin{array}{r}36.4 \\
42.1 \\
15.3 \\
6.2\end{array}$ & $\begin{array}{l}1.06 \\
1.61 \\
1.71\end{array}$ & $\begin{array}{l}0.84-1.33 \\
1.14-2.27 \\
1.02-2.88\end{array}$ & $\begin{array}{r}871 \\
598 \\
206 \\
59\end{array}$ & $\begin{array}{r}50.2 \\
34.5 \\
11.9 \\
3.4\end{array}$ & $\begin{array}{l}0.93 \\
1.80 \\
1.28\end{array}$ & $\begin{array}{l}0.79-1.10 \\
1.38-2.35 \\
0.83-1.96\end{array}$ & $\begin{array}{r}532 \\
422 \\
105 \\
42\end{array}$ & $\begin{array}{r}48.3 \\
38.3 \\
9.5 \\
3.8\end{array}$ & $\begin{array}{l}1.00 \\
1.00 \\
1.00\end{array}$ & $\begin{array}{l}\text { ref. } \\
\text { ref. } \\
\text { ref. }\end{array}$ \\
\hline \multicolumn{13}{|l|}{ Women } \\
\hline $\begin{array}{l}\text { Profusion } 0 / 0 \\
\text { Profusion } 0 / 1 \\
\text { Profusion } 1 / 0 \\
\text { Profusion } \geq 1 / 1\end{array}$ & $\begin{array}{r}11 \\
9 \\
7 \\
2\end{array}$ & $\begin{array}{r}37.9 \\
31.0 \\
24.1 \\
6.9\end{array}$ & $\begin{array}{l}0.53 \\
2.25 \\
1.92\end{array}$ & $\begin{array}{l}0.23-1.21 \\
0.88-5.77 \\
0.41-8.95\end{array}$ & $\begin{array}{r}777 \\
474 \\
106 \\
32\end{array}$ & $\begin{array}{r}44.8 \\
34.1 \\
7.6 \\
2.3\end{array}$ & $\begin{array}{l}1.10 \\
1.02 \\
1.04\end{array}$ & $\begin{array}{l}0.94-1.28 \\
0.78-1.32 \\
0.67-1.63\end{array}$ & $\begin{array}{r}1359 \\
773 \\
199 \\
62\end{array}$ & $\begin{array}{r}56.8 \\
32.4 \\
8.3 \\
2.6\end{array}$ & $\begin{array}{l}1.00 \\
1.00 \\
1.00\end{array}$ & $\begin{array}{l}\text { ref. } \\
\text { ref. } \\
\text { ref. }\end{array}$ \\
\hline
\end{tabular}


Table 3. Prevalence (\%) of and relative risk for pleural abnormalities by asbestos exposure among 3274 Finnish men and 3811 Finnish women. $(\mathrm{RR}=$ relative risk adjusted for age and smoking history, $95 \% \mathrm{Cl}=95 \%$ confidence interval, ILO = International Labour Office)

\begin{tabular}{|c|c|c|c|c|c|c|c|c|c|c|c|c|}
\hline \multirow[t]{2}{*}{ Pleural X-ray findings } & \multicolumn{4}{|c|}{$\begin{array}{l}\text { Probably exposed } \\
\qquad(N=439)\end{array}$} & \multicolumn{4}{|c|}{$\begin{array}{l}\text { Possibly exposed } \\
\quad(N=1734)\end{array}$} & \multicolumn{4}{|c|}{$\begin{array}{l}\text { Unlikely exposed } \\
\qquad(N=1101)\end{array}$} \\
\hline & $\mathrm{N}$ & $\%$ & $\mathrm{RR}$ & $95 \% \mathrm{Cl}$ & N & $\%$ & $\mathrm{RR}$ & $95 \% \mathrm{Cl}$ & $\mathrm{N}$ & $\%$ & $\mathrm{RR}$ & $95 \% \mathrm{Cl}$ \\
\hline \multicolumn{13}{|l|}{ Men } \\
\hline $\begin{array}{l}\text { LLO circumscribed pleural thickening, } \\
\text { bilateral }^{a}\end{array}$ & 45 & 10.3 & 2.67 & $1.71-4.17$ & 92 & 5.3 & 1.83 & $1.25-2.67$ & 44 & 4.0 & 1.00 & ref. \\
\hline $\begin{array}{l}\text { ILO circumscribed pleural thickening, } \\
\text { bilateral or unilaterala }\end{array}$ & 71 & 16.2 & 2.32 & $1.63-3.31$ & 171 & 9.9 & 1.86 & $1.39-2.48$ & 82 & 7.4 & 1.00 & ref. \\
\hline Pleural calcification & 53 & 12.1 & 2.92 & $1.92-4.44$ & 101 & 5.8 & 1.87 & $1.31-2.69$ & 50 & 4.5 & 1.00 & ref. \\
\hline $\begin{array}{l}\text { All findings indicating plaques of the } \\
\text { parietal pleura (circumscribed or local } \\
\text { thickening and/or calcification), bilateral }\end{array}$ & 57 & 13.0 & 3.01 & $2.00-4.53$ & 113 & 6.5 & 1.97 & $1.38-2.80$ & 51 & 4.6 & 1.00 & ref. \\
\hline $\begin{array}{l}\text { All findings indicating plaques of the } \\
\text { parietal pleura (circumscribed or local } \\
\text { thickening and/or calcification). }\end{array}$ & & & & & & & & & & & & \\
\hline bilateral or unilateral & 93 & 21.2 & 2.79 & $2.01-3.86$ & 219 & 12.6 & 2.11 & $1.61-2.76$ & 96 & 8.7 & 1.00 & ref. \\
\hline $\begin{array}{l}\text { ILO costophrenic angle obliteration, } \\
\text { bilateral or unilaterala }\end{array}$ & 27 & 6.2 & 1.24 & $0.76-2.02$ & 75 & 4.3 & 1.17 & $0.81-1.70$ & 53 & 4.8 & 1.00 & ref. \\
\hline $\begin{array}{l}\text { Thickening of the visceral pleura } \\
\text { (other than horizontal fissure) }\end{array}$ & 50 & 11.4 & 1.20 & $0.83-1.73$ & 156 & 9.0 & 1.25 & $0.95-1.65$ & 102 & 9.3 & 1.00 & ref. \\
\hline Thickening of the horizontal fissure & 34 & 7.7 & 1.71 & $1.07-2.72$ & 78 & 4.5 & 1.35 & $0.92-1.96$ & 51 & 4.6 & 1.00 & ref. \\
\hline $\begin{array}{l}\text { All pleural findings, parietal or visceral } \\
\text { Women }\end{array}$ & 175 & 39.9 & 2.17 & $1.68-2.80$ & 476 & 27.5 & 1.74 & $1.43-2.11$ & 262 & 23.8 & 1.00 & ref. \\
\hline $\begin{array}{l}\text { LLO circumscribed pleural thickening, } \\
\text { bilaterala }\end{array}$ & 3 & 10.3 & 7.21 & $1.94-26.8$ & 31 & 2.2 & 2.21 & $1.30-3.78$ & 26 & 1.1 & 1.00 & ref. \\
\hline $\begin{array}{l}\text { IL0 circumscribed ple ural thickening, } \\
\text { bilateral or unilateral }{ }^{2}\end{array}$ & 5 & 17.2 & 5.98 & $2.06-17.3$ & 55 & 4.0 & 2.11 & $1.41-3.15$ & 48 & 2.0 & 1.00 & ref. \\
\hline Pleural calcification & 2 & 6.9 & 2.73 & $0.61-12.2$ & 45 & 3.2 & 1.79 & $1.17--2.73$ & 47 & 2.0 & 1.00 & ref. \\
\hline $\begin{array}{l}\text { All findings indicating plaques of the } \\
\text { parietal pleura (circumscribed or local }\end{array}$ & & & & & & & & & & & & \\
\hline thickening and/or calcification), bilateral & 3 & 10.3 & 4.78 & $1.32-17.3$ & 38 & 2.7 & 1.88 & $1.18-2.99$ & 37 & 1.5 & 1.00 & ref. \\
\hline $\begin{array}{l}\text { All findings indicating plaques of the } \\
\text { parietal pleura (circumscribed or local } \\
\text { thickening and/or calcification), } \\
\text { bilateral or unilateral }\end{array}$ & 6 & 2.07 & 5.20 & $1.93-14.0$ & 66 & 4.8 & 1.79 & $1.25-2.56$ & 67 & 2.8 & 1.00 & ref. \\
\hline $\begin{array}{l}\text { ILO costophrenic angle obliteration, } \\
\text { bilateral or unilateral }\end{array}$ & 1 & 3.4 & 1.75 & $0.22-13.8$ & 32 & 2.3 & 1.87 & $1.12-3.10$ & 31 & 1.3 & 1.00 & ref. \\
\hline $\begin{array}{l}\text { Thickening of the visceral pleura } \\
\text { (other than horizontal fissure) }\end{array}$ & 2 & 6.9 & 1.34 & $0.30-5.95$ & 73 & 5.3 & 1.51 & $1.09-2.09$ & 91 & 3.8 & 1.00 & ref. \\
\hline Thickening of the horizontal fissure & 1 & 3.4 & 1.01 & $0.13-7.95$ & 31 & 2.2 & 1.17 & $0.74-1.86$ & 50 & 2.1 & 1.00 & ref. \\
\hline All pleural findings, parietal or visceral & 8 & 27.6 & 2.28 & $0.95-5.43$ & 185 & 13.3 & 1.51 & $1.22-1.88$ & 236 & 9.9 & 1.00 & ref. \\
\hline
\end{tabular}

a Classified strictly according to the ILO classification.

Table 4. Parallel ratings of 227 lifetime job histories by two experts and repeated ratings of 299 lifetime job histories by the same expert according to the probability of occupational exposure to asbestos. $(A=$ probable exposure, $B=$ possible exposure, $C=$ unlikely exposure)

\begin{tabular}{lrrrr}
\hline \multirow{4}{*}{ 1st rater } & \multicolumn{5}{c}{ Parallel ratings } \\
& 2nd rater \\
\cline { 2 - 5 } & A & B & C & Total \\
\hline A & 18 & - & - & 18 \\
B & - & 95 & 10 & 105 \\
C & - & 12 & 92 & 104 \\
Total & 18 & 107 & 102 & 227 \\
\hline
\end{tabular}

\begin{tabular}{lrrrr}
\hline \multirow{2}{*}{ 1st rating } & \multicolumn{5}{c}{ Repeated ratings } \\
& \multicolumn{5}{c}{ 2nd rating } \\
\cline { 2 - 5 } & A & B & C & Total \\
\hline A & 28 & 3 & - & 31 \\
B & - & 111 & 1 & 112 \\
C & - & 12 & 144 & 156 \\
Total & 28 & 126 & 145 & 299 \\
\hline
\end{tabular}

rater agreement of repeated evaluations was $95 \%$ (kappa 0.91). In none of the cases did the ratings deviate more than one exposure category (table 4 ).

When the lifetime work histories were compared with the exposure classification of the latest or current occupation, the overall agreement was 66\% (kappa 0.53) for the men and $77 \%$ (kappa 0.75 ) for the women. In several

cases the ratings were upgraded from unlikely exposure to possible or probable exposure because of previous occupations not regarded in the classification based on the latest or current occupation only (table 5). In the results the lifetime job history was used as the basis for the asbestos exposure classification as it provided the best available data. 


\section{Discussion}

According to our results, past exposure to asbestos is common in the Finnish population. It plays a significant role in the etiology of both pleural abnormalities and small lung opacities indicating pulmonary fibrosis, not only in certain exposed cohorts but also at the level of the general population. For the men about $40 \%$ of the bilateral pleural plaques, $20 \%$ of the fissure thickening, and $30 \%$ of the small lung opacities (ILO $\geq 1 / 0$ ) were attributable to occupational asbestos exposure. For the women the etiologic fractions for asbestos exposure were only slightly lower in cases of pleural abnormalities, but clearly lower in cases of parenchymal fibrosis. As some of the radiographic abnormalities among those with unlikely exposure may be related to atypical or shortterm unrecognized occupational exposure to asbestos, the etiologic fractions probably underestimated the true effect of occupational exposure to asbestos. Our approach also neglects the role of domestic environmental asbestos exposure. Environmental exposure to anthophyllite asbestos has been associated with a high prevalence of pleural plaques in the area around the Paakkila asbestos mine (13). None of the localities of this area were included in the two-stage stratified cluster sample of our study $(10)$.

From the etiologic fractions and the national population statistics it can be calculated that there are at least 80000 Finnish men with radiologically detectable bilateral pleural plaques and that at least 35000 of these cases are associated with occupational exposure to asbestos. The latency time for radiographic asbestos-associated abnormalities is long, and the maximum of annual use of asbestos in Finland was reached at the beginning of the 1970s (9). The full effect of this maximum in exposure should thus not yet be detectable in our study, based on radiographs taken in 1979-1981.

The prevalence of bilateral pleural plaques among the adult men $(6.8 \%)$ in our study population is higher than the $2.7 \%$ in a Swedish health survey in Uppsala $(14,15)$ and the $1.8 \%$ in Telemark, Norway (16). The prevalence of pleural and parenchymal abnormalities increases with age (12), and an association between smoking history and small irregular lung opacities was found in this sample, as will be reported in a separate paper submitted for publication. Therefore direct comparisons of prevalences are difficult because of the difference in age distribution, and probably also smoking history, between the study populations. It seems obvious, however, that the prevalence of pleural plaques is especially high in Finland. The prevalence of bilateral plaques among women in our study $(2.0 \%)$ is similar to that observed for men in other Nordic countries. Anthophyllite asbestos has been produced and widely used in Finland. The risk of pleural plaques associated with elevated pulmonary
Table 5. Classification of occupational exposure to asbestos according to lifetime job history and current or latest occupation. $(A=$ probable exposure, $B=$ possible exposure, $C=$ unlikely exposure)

\begin{tabular}{lrrrr}
\hline Latest occupation & \multicolumn{4}{c}{ Lifetime job history } \\
\cline { 2 - 5 } & A & \multicolumn{1}{c}{ B } & C & Total \\
\hline Men & & & & \\
A & 269 & 111 & 3 & 383 \\
B & 121 & 851 & 55 & 1027 \\
C & 49 & 774 & 1047 & 1870 \\
Total & 439 & 1736 & 1105 & 3280 \\
Women & & & & \\
A & 15 & 15 & - & 30 \\
B & 13 & 578 & 51 & 642 \\
C & 1 & 798 & 2344 & 3143 \\
Total & 29 & 1391 & 2395 & 3815 \\
\hline
\end{tabular}

concentrations of anthophyllite fibers seems to be similar if not lower than that associated with crocidolite or amosite fibers (17). It is, however, possible that a significant portion of plaques among Finns are attributable to anthophyllite exposure because of its wide industrial use in several domestic products, as well as its former use as friable insulation material in houses and heating systems (18). The number of persons exposed to anthophyllite has been much higher than the number of persons exposed to crocidolite or amosite (9).

Although thickening of the visceral pleura may not only occur as diffuse thickening, but also as local plaques, most radiographic circumscribed pleural thickenings represent plaques of the parietal pleura $(2,19)$. In addition to the definition of circumscribed pleural thickening of the ILO classification, other diagnostic criteria for pleural plaques have been proposed (2). We used both the ILO classification and a broader definition of plaques. The prevalence of plaques conforming to the latter definition was higher, but the asbestos-related risk estimates were similar.

The ILO classification is based on comparison with a set of standard posteroanterior radiographs. The standard radiographs with small irregular lung opacities demonstrate a pattern for asbestos-exposed persons with interstitial lung fibrosis. A similar appearance may result from other causes (1). The classification does not imply legal definitions of pneumoconiosis, but the radiographic criterion for pneumoconiosis is often expressed as a minimum grade (usually $\geq 1 / 0$ or $\geq 1 / 1$ ) according to the ILO classification $(20,21)$. It is, however, noteworthy that the chest radiograph may be normal in persons with interstitial lung fibrosis, as demonstrated by high resolution computed tomography (HRCT) or biopsy $(22,23)$.

It has been concluded that thickening of the horizontal fissure may indicate the presence of pulmonary fibrosis, even in radiographically normal lungs, and may thus 
be an early sign of asbestosis (3, 24). Fissure thickening has also been regarded as a purely pleural abnormality with no connection to parenchymal fibrosis (25). In a previous report concerning the sample a positive association was found between thickening of the horizontal fissure and parenchymal opacities, and in the present study the risk of thickened horizontal fissure was increased among asbestos-exposed persons. The risks of visceral pleural abnormalities other than fissure thickening were not significantly increased among the asbestosexposed persons. This finding probably reflects the fact that these abnormalities have other important etiologic agents (3).

The consistency of the asbestos-exposure classifications based on the latest occupation only and the lifetime job history was $66 \%$ for the men and $77 \%$ for the women. When the exposure classification based on the latest occupation only was used in the statistical calculations, the risk estimates for pleural and parenchymal abnormalities were similar to those presented in tables 2 and 3 , but their statistical significance was lower (not shown). The inter- and intrarater consistency in the exposure classification was more than $90 \%$. It must be emphasized that this high percentage was achieved by two raters who had classified several similar job history series together.

\section{Concluding remarks}

Occupational asbestos exposure has been common among men in Finland. Occupational exposure to asbestos plays an important role in the etiology of radiographic pleural and pulmonary abnormalities also at the level of the general population in Finland.

\section{Acknowledgments}

We thank Helena Helle, Ulla Olkkonen, Salme Rämö, and other members of the staff of The Research and Development Centre of the Social Insurance Institution and Pirkko Kinberg, Maila Rastas, and Liisi Timonen of the Finnish Institute of Occupational Health for their valuable assistance.

\section{References}

1. van Ordstrand HS. Pneumoconioses and their masqueraders. J Occup Med 1977; 19:747—53.

2. Järvholm B, Arvidsson H, Bake B, Hillerdal G, Westrin C-G. Pleural plaques - asbestos - ill health. Eur J Respir Dis 1986;68 suppl 145:1-59.
3. Rosenstock L, Hudson LD. The pleural manifestations of asbestos exposure. In: Rosenstock L, editor. Occupational pulmonary disease. Philadelphia (PA): Hanley \& Belfus, 1987:383 - 407. Occupational medicine: state of arts reviews, vol 2 , no 2 .

4. International Labour Office (ILO). Guidelines for the use of ILO international classification of radiographs of pneumoconioses: revised edition. Geneva: ILO, 1981. ILO occupational safety and health series, no 22 (rev 80).

5. Koskinen K, Rinne J-P, Zitting A, Kivekäs J, Roto P, Karjalainen $A$, et al. Screening and follow-up of asbestos-exposed workers in Finland. In: Hurych J, Lesage M, David A, editors. Proceedings of the 8th International Conference on Occupational Lung Diseases, Prague 14-17.9.1992; vol 1. Geneva: International Labour Office, 1993:368 - 71 .

6. Oksa P, Koskinen H, Rinne JP, Zitting A, Roto P, Huuskonen MS. Parenchymal and pleural fibrosis in construction workers. Am J Ind Med 1992;21:561-7.

7. Wegelius $\mathrm{C}$. Changes in the lungs in 126 cases of asbestosis observed in Finland. Acta Radiol 1947;28:139-52.

8. Ministry of Labour. Asbestikomitean mietintö [Report of the Asbestos Committee]. Helsinki: Ministry of Labour, 1989. Report series of the governmental committees, no 66. English summary.

9. Karjalainen A, Vanhala E, Karhunen P, Lalu K, Penttilä A, Tossavainen A. Asbestos exposure and pulmonary fiber concentration of 300 Finnish urban men. Scand J Work Environ Health 1994;20:34-41.

10. Aromaa $A$, Heliövaara $M$, Impivaara $O$, Knekt $P$, Maatela J Mini-Suomi-terveystutkimuksen toteutus: osa 1. tavoitteet, menetelmät ja aineisto [Aims, methods and study population, The Mini-Finland Survey, part 1]. Helsinki, Turku (Finland): Kansaneläkelaitos, 1989:21—4. Kansaneläkelaitoksen julkaisuja ML:88.

11. Ministry of Transport and Public Works. The Nordic classification of occupations. Helsinki: Ministry of Transport and Public Works, 1993.

12. Zitting AJ. Prevalence of radiographic small lung opacities and pleural abnormalities in a representative adult population sample. Chest 1995;107:126-31.

13. Kiviluoto R. Pleural calcification as a roentgenologic sign of non-occupational endemic anthophyllite-asbestosis. Acta Radiol 1960; suppl 194: $67 \mathrm{p}$.

14. Hillerdal G. Pleural plaques and the risk for bronchial carcinoma and mesothelioma. Chest 1994;105:144-50.

15. Hillerdal G. Pleural plaques in the general population. Ann NY Acad Sci 1991;643:430 - 7 .

16. Hilt B, Lien JT, Lund-Larsen PG, Lund K, Langård S. Asbestos-related findings in chest radiographs of the male population of the county of Telemark, Norway: a cross-sectional study. Scand J Work Environ Health 1986;12:567-73.

17. Karjalainen A, Karhunen P, Lalu K, Penttilä A, Kyyrönen P, Tossavainen A. Pleural plaques and exposure to mineral fibres in a male urban autopsy population. Occup Environ Med $1994 ; 51: 456-60$.

18. Riala R, Pirhonen P, Heikkilä P. Asbesti purku- ja huoltotöissä [Asbestos in building renovation: use, exposure and dust prevention]. Helsinki: Finnish Institute of Occupational Health, 1993.

19. Lynch DA, Gamsu G, Aberle D. Conventional and high resolution computed tomography in the diagnosis of asbestosrelated diseases. Radiographics 1989;9:523-51.

20. US Public Health Service. Code of federal regulations (CFR), part 37: specifications for medical examinations for under- 
ground coal miners, $\$ 37.7$. Washington (DC): US Public Health Service, 1989:146.

21. American Thoracic Society. Statement on diagnosis of nonmalignant diseases related to asbestos. Am Rev Respir Dis $1986 ; 134: 363-8$.

22. Aberle DR, Gamsu G, Ray CS, Feuerstein IM. Asbestosrelated pleural and parenchymal fibrosis: detection with highresolution CT. Radiology 1988;166:729-34.

23. Akira M, Yamamoto S, Yokoyama K, Kita N, Morinaga K, Higashihara T, et al. Asbestosis: high-resolution CT - patho- logic correlation. Radiology 1990;176:389—94.

24. Rockoff SD, Kagan E, Schwartz A, Kriebel D, Hix W, Rohatgi $\mathrm{P}$. Visceral pleural thickening in asbestos exposure: the occurrence and implications of thickened interlobar fissures. J Thorac Imag 1987;4:58-66.

25. Zejda J, Ernst P. Fissure thickening and exposure to asbestos: occurrence, determinants and functional impact. Am J Ind Med 1991;20:785-93.

Received for publication: 20 February 1995 